\title{
RESEARCH ON WILLINGNESS TO STUDY NURSING, EDUCATION AND SOCIAL WORKS AMONG SENIOR MALE STUDENTS IN VYSOCINA REGION
}

\section{Martina Chalupová, Jana Borůvková}

\begin{abstract}
This paper summarizes the results of the research that centered on the decision-making process of senior male students in the Vysocina Region for a field of study on a higher education institution. The survey was administered to male students in their last year of the high school who were enrolling for the first time. The focus of the research was on the choice factors. The particular aim was to find out whether the male students were considering as their field of study nursing, education and social works; majors that are traditionally dominated by women. Spearman's rank correlation coefficients were used to measure statistical dependence between choice factors and the tendency to choose ,female profession'.
\end{abstract}

\section{Key Words}

Senior male students, major choice, Vysocina Region, Spearman's rank correlation coefficients
Czech University of Life Sciences Prague martina.chalupova@email.cz

\section{ARTICLE INFO}

Article type

Full research paper

doi: 10.7160/eriesj.2012.050202

Article history

Received: April 30, 2012

Received in revised form: June 24, 2012

Accepted: June 29, 2012

Available on-line: June 30, 2012

Chalupoví, M., Borůvková, J. (2012) "Research on Willingness to Study Nursing, Education and Social Works Among Senior Male Studenst in Vysocina Region", Journal on Efficiency and Responsibility in Education and Science, Vol. 5, No. 2, pp. 63-77, ISSN 1803-1617, [on-line] www.eriesjournal.com/_papers/article_173.pdf [2012-06-30]. doi: 10.7160/eriesj.2012.050202 


\section{Introduction}

Higher education institutions in the Czech Republic are facing increasingly complex challenges, which demand deeper understanding of the sources prospective students use when applying to a college or a university. Currently the Czech system of higher education comprises of twenty-six public universities that offer a wide range of study fields within bachelor, master and doctoral study programmes and two non-university public institutions of higher education which provide bachelor study programmes only. The sector also includes fourty-six private higher education institutions. ${ }^{1}$ The number of colleges and universities has rised dramatically. In 2000 the system of higher education in the Czech Republic consisted of twentyfour public and eight private institutions. In the meantime, the demographic curves clearly indicate the stagnation of the size of higher education age groups. Political development seeking rationalisation of the higher education system is leading to managerial and funding challenges for higher education institutions. Overall, these factors intensify the competition and understanding the decision-making process of the prospective students is of extreme importance (Moogan, 2011; Hoyt and Brown, 2003).

The decision what university or college to attend has been characterised as a highly complex process that is subject to multiple influences. Studies in higher education are founded in several disciplines, including economics (e.g. Perna, 2008; Des Jardins et al., 2006; Avery and Hoxby, 2004), public policy (e.g. Dill, 1997) and sociology (e.g. Porter and Umbach, 2006; Menclova and Bastova 2005; Galloti and Mark, 1994).

$\overline{1}$ Data from academic year 2011/2012 (September), Source: Ministry of Education, Youth and Sports of the Czech Republic
Understanding how students make decisions regarding the college selection has led to the development of several student behaviour models. One of the most widely used models is Hossler and Gallagher's three-stage model (1987). The first stage is predisposition, in which students develop aspirations for college attendance, in the second stage they search for information about colleges and develop a choice set and as the third stage they choose the particular college.

The model draws simultaneously on the rational approach and the sociological perspective, providing a comprehensive explanation about the final choice (Hossler, Schmit, and Vesper 1999). Other representative combined models were proposed by Jackson (1982), Litten (1982) or Cabrera and La Nasa (2000).

Vrontis, Thrassou, and Melanthiou (2007) built on such contributions and presented a contemporary higher education student-choice model for developed countries. The model consideres both the sequence of the decision steps and various influences. These determinants include: (1) environment (general public policy and influences/media), (2) high school characteristics (e.g. social composition, quality), (3) higher education institutions (characteristics and actions), and (4) individual (customer and personal attributes). Using these models as a background, this study focuses on information search and choice factors.

\section{Information search}

Sources of information can be identified as internal - memory or knowledge from previous related experience and external - involves collecting new information from both personal and non-personal sources (Hawkins, Mothersbaugh, Best, 2009). Studies assessing students' information requirements and relevance have found that students tend to rely primarily on 
information sources developed by the education institutions (e.g. brochures, leaflets, university websites). Soukalova (2009) made a research in the Czech Republic and found out, that the students when searching for the information about the fields of study at college or university rely the most on internet sources. The same results were shown in a study in Scotland (Briggs and Wilson, 2007). Simoes and Soares' (2010) findings revealed that Portugese students that chose the fields of health studies and sciences relied significantly on the university website as on an information source.

Cultural differences can be found concerning the importance of interpersonal communication. Soukalova's findings (2009) revealed that the second most influential source of information for the Czech students, when deciding about the field of study, is parents and friends (personal recommendations). Parental influences have been found to be among the highest predictors of a student's enrollment in college in the USA (Hossler, Schmit, and Vesper, 1999). In Portugal, according to Simoes and Soares (2010) research, personal influences (family/current $A B C$ University students) were the most important choice factor for only $8 \%$ of the respondents. Briggs and Wilson (2007) state: 'Decisions are based on a combination of information available, word of mouth, perceptions and institution's reputation. Prospective students seek advice from social networks (e.g. friends/acquaintances, teachers) as well as from the formal sources.'

A connection between preference for information sources and individual factors can be established. In particular, regarding higher education services, Vrontis, Thrassou, and Melanthiou (2007) identified several determinants of student behaviour, such as academic aptitude, gender and personality. Also, Briggs and Wilson (2007) found evidence of gender and discipline differences for information sources. Dolinsky's (2010) study findings suggested different communication strategies for males for some of the college-related attributes (job placement after graduation and financial aid).

\section{Choice factors}

Choosing which higher education institution to apply to is a high perceived risk decision, given its long-term implications on students' lives and careers. The selection is influenced by a broad range of choice factors. Literature does not provide any consensual and comprehensive group of choice factors, although various studies directly or indirectly approach the matter. Choice factors are dependent on the study's context. For example Kallio (1995) reports six categories of factors when selecting a graduate school: characteristics of the academic environment of the institution and its programmes, residency status, financial support, spouse considerations, the social environment of campus life, and work-related concerns.

We highlight the following choice factors according to their relevance to this study: parental influence, gender and economic crises (the influence of media reporting about the matter of and personal experience with unemployment in the family and among friends).

Lackland (2001) had suggested that sex-role reinforcement is the reason for gender differences in the major choice, explaining that women tend to choose disciplines like education or nursing because of their female gender role orientation. Kanter (1993) uses the theory of proportions in the social life to argue that the minority status within an organization reinforces traditional roles and places constraints on women. A relatively few number of women in, for example science and technical fields places high pressure on the few who have chosen those fields, resulting in greater likelihood of departure. Kanter's (1993) theory of 
proportions can be used to explain the fact that in the Czech Republic, there is still minimum men who choose nursing as their field of study.

The economic crisis, a relatively new phenomenon of the environment, and its influence on the college or university choice should be taken into account. The most important surveys carried out in the field of higher education in the Czech Republic summarized by Minksova (2010) showed that the economic crisis as a factor influencing the decision-making process of the high school students considering their choice of the future field of study has not yet been deeply researched.

\section{Materials and Methods}

The aim of the research (conducted in March 2011) was to determine whether the male students in their last year at high school in the Vysocina Region considered as their field of study nursing, education and social works; majors that are traditionally dominated by women. The other aim was to find out if an economic crisis can be a factor that would make an impact on these students' choice. Whether they consider education, nursing and social works, the fields that are touched less by the economic crisis, and therefore can be considered as newly prospective fields.

Given this purpose, this study attempts to answer the following research questions:

1. What are the factors that influence the choice of the field of study of male students who are in their last year at high school in the Vysocina Region?

2. Is there any correlation between choice factors and the tendency to choose majors such as education, nursing and social works?
3. Do senior male students consider nursing, education and social works as their field of study?

This research followed a quantitative design and was carried out at selected secondary schools in the Vysocina Region in cooperation with the secondary schools' management following preliminary discussions and their agreement. Due to the research objectives, the so-called non-comprehensive selection was performed, which requires investigation only at a specific sample of units. Only grammar schools, business academies and engineering schools students were included. High schools specialised in education, healthcare and social works were excluded, as their students had already chosen this field of study. After interviews with directors of high schools specialised in agriculture, automotive, graphics, arts and veterinary medicine, their students were not included in research either.

The research sample included 23 private and public schools, all of them located in the Vysocina Region exclusively, which represents $76 \%$ of all the grammar schools, business academies and engineering schools (see Table 1). 


\begin{tabular}{|l|c|c|c|}
\hline Districts & $\begin{array}{c}\text { Actual number of } \\
\text { the chosen high } \\
\text { schools in the } \\
\text { district }\end{array}$ & $\begin{array}{c}\text { High schools } \\
\text { that agreed to } \\
\text { participate in the } \\
\text { research }\end{array}$ & Percentage \\
\hline $\begin{array}{l}\text { Havlickuv } \\
\text { Brod }\end{array}$ & 8 & 4 & $50 \%$ \\
\hline Jihlava & 6 & 6 & $100 \%$ \\
\hline Pelhrimov & 4 & 3 & $75 \%$ \\
\hline Trebic & 7 & 5 & $71.4 \%$ \\
\hline $\begin{array}{l}\text { Zdar nad } \\
\text { Sazavou }\end{array}$ & 7 & 5 & $83.3 \%$ \\
\hline Total & 32 & 23 & $76.7 \%$ \\
\hline
\end{tabular}

Table 1: Number of grammar schools, business academies and engineering schools in 2010/11

Source: Department of Statistics of the Vysocina Region and our own data

In 2010/11 the number of prospective respondents, i.e. male students that studied in their last year at a chosen high school (grammar schools, business academies and engineering schools), was 1231. The actual number of respondents was 386, which represents $31 \%$. Students were distributed across the following types of high schools: grammar schools $216(56 \%)$ and business and engineering schools 170 (44\%).

The questionnaire consisted of 16 questions and was applied as an on-line survey to male students in their last year at high school in the Vysocina Region enrolling at a university for the first time. Directors of the high schools agreed that students would fill in the questionnaire in their classes. They were sent instructions and a web link.
The questionnaire was developed to identify students' choice factors and influences when applying to higher education institution and the choice of a specific field of study. The question "Evaluate the factors that influenced your decision regarding your future study" aimed at determination of the weight of factors that have played some role in the decisionmaking of respondents. This question was a matrix type, with a scale between 1 and 4 ( 1 = major influence, $4=$ no influence $)$. Factors that have been selected:

- The field of study currently offers career security

- Job prestige

- The field of study is currently "profitable“

- Distance of the place of study from home

- Financial demands of study

- Easy admission conditions

- My parents recommended this field of study

- My friends decided to study this field

Respondents were also asked to reply whether they considered the profession of:

- Nursery school teacher

- Elementary school teacher

- Secondary school teacher

- Nurse

- Social worker

Possible answers to these questions:

- Yes, I would like this occupation

- Considered, but chose another

- No 
Based on these questions, a new ordinal variable was constructed: "tendency to choose female occupation". This variable was created as the sum of values that replaced variants of answers: Yes, I would like this occupation $=2$, Considered, but chose another $=1$ a No $=0$. These values were summed up for each respondent creating a variable that quantifies the tendency to choose a female occupation.

This variable varied within the interval from 0 to 7 , which means that some respondents chose the answer Yes, I would like this occupation more than once. In these cases, it was a combination of the fields of study that is possible to study simultaneously. Only one student chose all five possibilities, and his answers were excluded from the analysis.

Spearman's rank correlation coefficients were used to measure statistical dependence between choice factors and the tendency to choose ,female profession', using software STATISTICA 11.1. Spearman's rank correlation coefficient is a non-parametric measure of statistical dependence between two ordinal variables (Zar, 1974). It is based on individuals rank numbers. Individuals are ranked by size according to both observed variables. Each individual is connected with the pair of rank numbers: $Q$ (rank number according to the first variable $X$ ) and $R$ (rank number according to the second variable $Y$ ). For $n$ observed pairs from the sample we set Spearman's rank correlation coefficient using the rank numbers difference $d_{i}=Q_{i}-R_{i}$ (Zar, 1974):

$$
r_{s}=1-\frac{6 \cdot \sum_{i=1}^{n} d_{i}{ }^{2}}{n \cdot\left(n^{2}-1\right)}
$$

In case of rank numbers concordance all values $d_{i}=0$, thus $r_{s}=1$. In case of rank numbers reverse $r_{s}=-1$. In other situation of rank numbers discordance Spearman's rank correlation coefficient takes values from interval between these two boundary numbers:

$$
-1 \leq r_{s} \leq 1
$$

For the values of $r_{s}$ near 0 we can consider that rank numbers $R$ and $Q$ are ordered randomly and there does not exist any dependence between variables $X$ and $Y$.

Next step of Spearman's (rank) correlation coefficient calculation is the significance test of this coefficient. We set null hypothesis: $\mathrm{H}_{0}: r_{s}=0$ and if the test $\mathrm{p}$-value exceeds 0.05 , variables $X$ and $Y$ are independent with probability at least $95 \%$.

\section{Results}

Values for each variable were summed according to the importance that respondents linked to the factor. The factors were then sorted by the importance, from the lowest sum that represents the most significant factor (see Table 2).

\begin{tabular}{|l|r|}
\hline The field of study currently offers career security & 772 \\
\hline Job prestige & 836 \\
\hline The field of study is currently "profitable" & 879 \\
\hline Distance of the place of study from home & 1,087 \\
\hline Financial demands of study & 1,1 \\
\hline Easy admission conditions & 1,143 \\
\hline My parents recommended this field of study & 1,229 \\
\hline My friends decided to study this field & 1,323 \\
\hline
\end{tabular}

Table 2: Factors that influence the student's choice of the field of study sorted by the importance (lower sum means more significant factor) 
As there are no continuous numeric variables, Spearman's rank correlation coefficients were used to measure statistical dependence between choice factors and the tendency to choose ,female profession' (see Table 3). Bold coefficients are statistically significant on the significance level 0.05 , other correlation coefficients must be considered as zero and variables are uncorrelated.

\begin{tabular}{|l|c|}
\hline The field of study currently offers career security & 0.065 \\
\hline Job prestige & 0.089 \\
\hline The field of study is currently "profitable" & $\mathbf{0 . 1 4 5}$ \\
\hline Distance of the place of study from home & -0.045 \\
\hline Financial demands of study & -0.054 \\
\hline Easy admission conditions & 0.025 \\
\hline My parents recommended this field of study & 0.011 \\
\hline My friends decided to study this field & $\mathbf{0 . 1 3 6}$ \\
\hline
\end{tabular}

Table 3: Spearman's rank correlation coefficient between the choice factors and tendency to choose ,female profession'

(Bold coefficients are statistically significant, the significance level 0.05)

Spearman's rank correlation coefficients values sorted in Table 3 demonstrate very weak causality between motives "the field of study is currently profitable“ and "my friends decided to study this field" on one side and "tendency to choose female profession" on the other.

Those who tend to choose education, nursing or social works as their future occupation are less affected by the profitability of the job or friends' opinion.

The research further proved that one-fifth of the households included in the survey were affected by unemployment (see
Fig. 1). Those not contemplating further study did not answer this question (12 respondents).

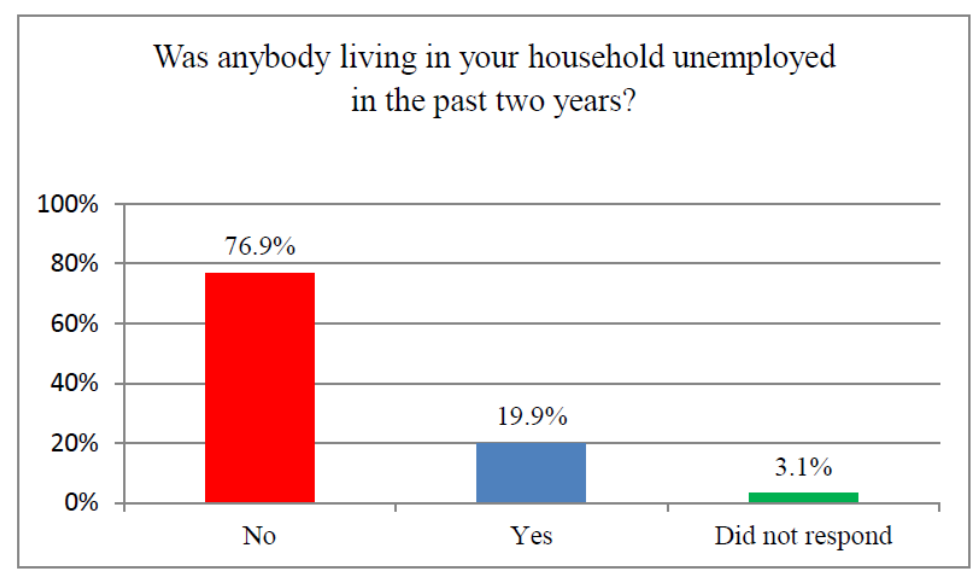

Figure 1: The unemployed in the households of the boys preparing for the graduation exam in 2010/11 over the past two years

The most frequently unemployed member in the households of the future secondary school graduates in the Vysocina Region was mother $(46.8 \%$ of the 77 respondents who mentioned a household member without any job for the recent two years). As further explained by Fig. 2, father was the unemployed household member in $26(33.8 \%)$ of the cases. A total of $15.6 \%$ of the future graduates shared their households with an unemployed brother or sister. 


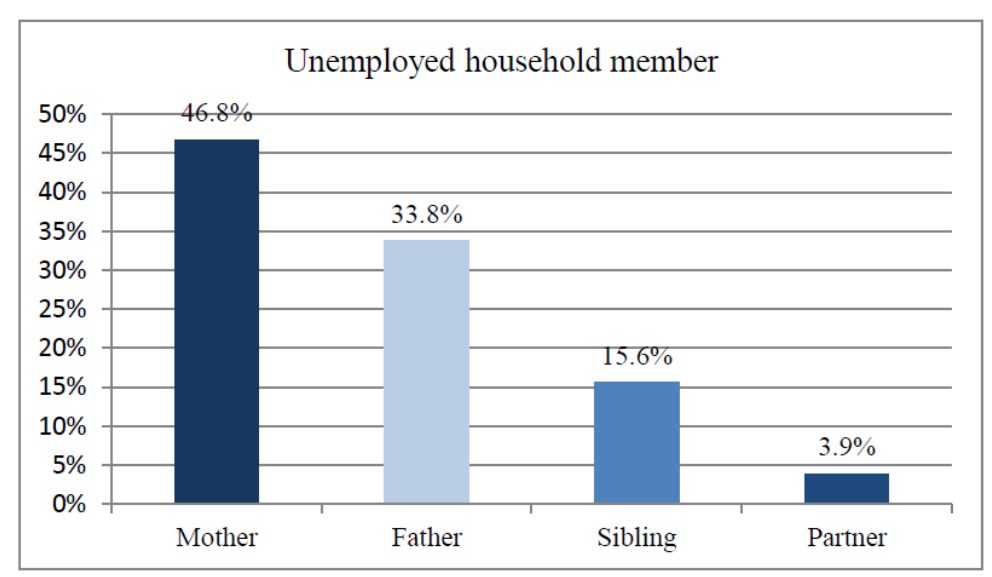

Figure 2: The unemployed in the households of the future graduates over the past two years - specific members

According to the survey, the influence of unemployment in the households of the future graduates was not significant (see Fig. 3 ). This fact had a major or rather important influence on the decision regarding the future field of study for only $9.1 \%$ of the respondents. A total of $81.5 \%$ of the males mentioned no or a lesser influence by this factor.

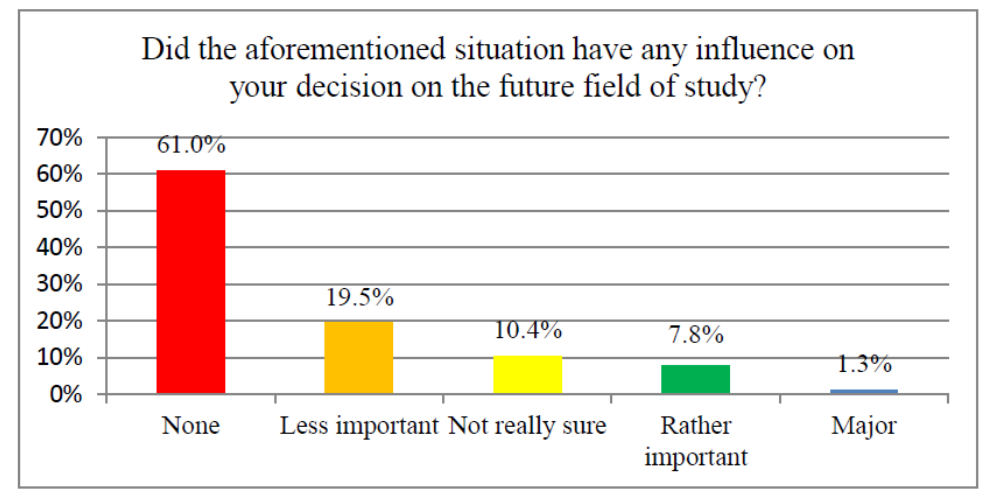

Figure 3: The unemployed in the households of the future graduates over the past two years - influence on the decision on the specific field of study

The future graduates were exposed to a rather intensive news coverage concerning the recession; see Fig. 4. However, only $5.8 \%$ of the respondents admitted active searching for this sort of information. Yet, the media influence is substantial - more than $63 \%$ of the males took regular notice of events related to economic problems. A mere $6.8 \%$ of the respondents did not follow the information at all. A strong interest in economic studies has, thus, been demonstrated. 


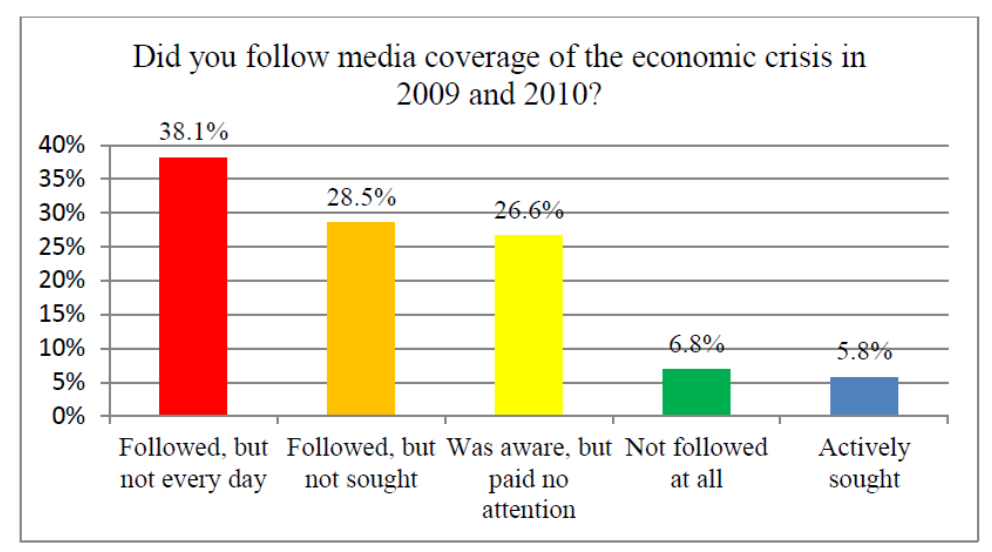

Figure 4: Following the news coverage of the economic crisis by the future graduates in the Vysocina Region in 2009-2010

As seen in Tab. 4, respondents considered the banking sector as the worst hit by the economic crisis while the supposedly least affected one is the computer technology domain. The monitored areas - social services and health care - were seen on the basis of the information collected from the media as those not seriously impacted by the crisis. Quite surprisingly, the educational system was perceived as bearing above-average consequences of the crisis. It is also of interest that the respondents did not consider any of the offered areas as strongly affected by the crisis. The scale was between 1 and $4(1=$ strong effects of the crisis on the area, $4=$ no effects of the crisis on the area).

\begin{tabular}{|l|r|}
\hline Banking sector & 1.72 \\
\hline Insurance & 1.98 \\
\hline Services & 2.10 \\
\hline Social services & 2.11 \\
\hline Health care & 2.18 \\
\hline Construction & 2.20 \\
\hline Transport & 2.26 \\
\hline Heavy industry & 2.32 \\
\hline Electrical engineering & 2.57 \\
\hline Education & 2.69 \\
\hline Mininig & 2.70 \\
\hline Computers & 2.75 \\
\hline
\end{tabular}

Table 4: Economic area affected by the crisis in the view of the male students preparing for the graduation exam in the Vysocina Region, influenced by media coverage in 2010/11

The reasearch was conducted in March 2011, most of the students had already made their decision on their field of study, some of them chose more than one study programme. The majority (more than 31\%) picked economics (business, management or finances). Surprisingly, a high percentage of the male students chose education (slightly over 10\%). Nursing and social works were the least popular (see Table 5). 


\begin{tabular}{|l|c|r|}
\hline Programmes & $\begin{array}{c}\text { Actual } \\
\text { number }\end{array}$ & Percentage \\
\hline Business, finance and management & 121 & $31.4 \%$ \\
\hline Humanities and arts & 81 & $21 \%$ \\
\hline Technologies & 66 & $17.1 \%$ \\
\hline Education & 40 & $10.4 \%$ \\
\hline Law & 35 & $9 \%$ \\
\hline Natural sciences & 28 & $7.3 \%$ \\
\hline Medicine and pharmacy & 27 & $7 \%$ \\
\hline Other medicine (nursing) & 13 & $3.4 \%$ \\
\hline Social & 9 & $2.3 \%$ \\
\hline
\end{tabular}

Table 5: Choice of the field of study - male students preparing for the graduation exam in the Vysocina Region in 2010/11

The crucial part of the research concerned the interest of future graduates of secondary schools in the Vysocina Region in studying those fields that would prepare them for the occupations of a nursery/elementary/secondary school teacher, nurse or social worker.

A total of 11 males showed an interest in becoming a nursery school teacher, i.e. $2.8 \%$ of the total number (see Fig. 5). This population was divided by the type of the secondary school - 8 respondents studied grammar schools and 3 technical secondary schools. However, a direct identification with the given field of study in question no. 2 (Could you tell us which field or fields of future study you have chosen?) was recorded in only 2 respondents. Yet, the general answer "pedagogy" or "education“ appeared quite frequently. Almost one-sixth of the population, $15.5 \%$ to be exact, considered this career path. Of these, 36 studied the grammar school, 24 studied a business/ engineering secondary school.

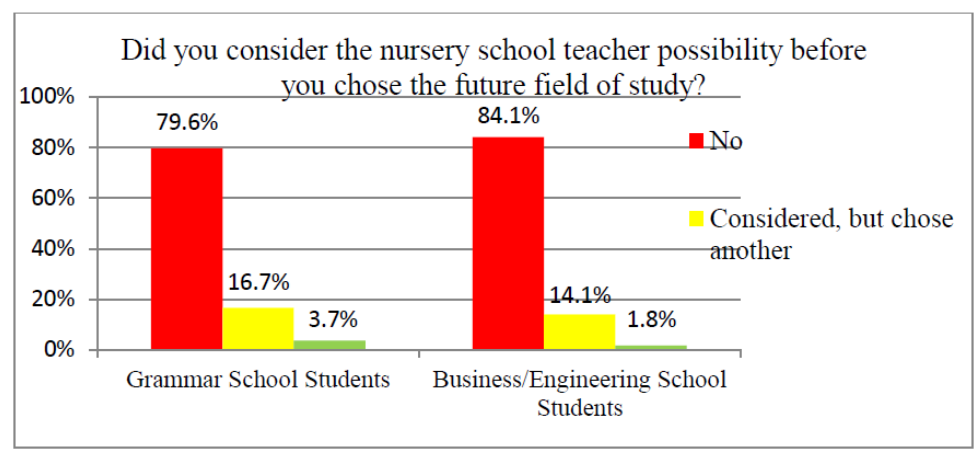

Figure 5: Interest in the nursery school teacher job among the future graduates in the Vysocina Region in 2011

As seen in Fig. 6, 17 boys preparing to take the graduation examination $(4.4 \%)$ showed an interest in the elementary school teacher profession. The majority of these (15) studied the grammar school, 2 studied a business/engineering secondary school. Once again, there is a high percentage of those who may have considered this option, but finally chose a different career $(16.8 \%)$. Grammar school students prevail (42), while there were 23 students interested in this profession at business/engineering secondary schools. 


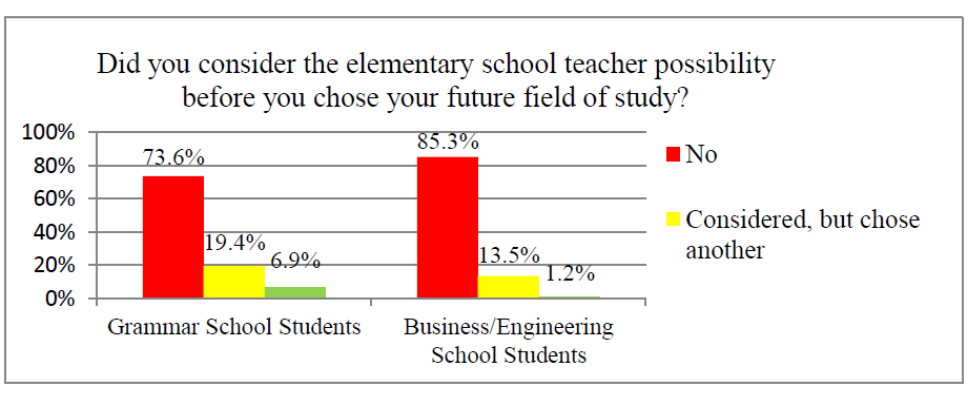

Figure 6: Interest in the elementary school teacher profession among future graduates in the Vysocina Region in 2011

A total of $9 \%$ of the respondents mentioned an interest in the job of a secondary school teacher, which is the most positive reaction of all the offered positions within the educational system. There is a majority of grammar school students (31) compared to 4 students interested in this job currently studying at the business/engineering schools. More than $23 \%$ of the students contemplated this possibility, but finally opted for another field of study; see Fig. 7. Again, grammar school students prevail (70) over the business/engineering schools (21).
Did you consider the secondary school teacher possibility before you chose your future field of study?

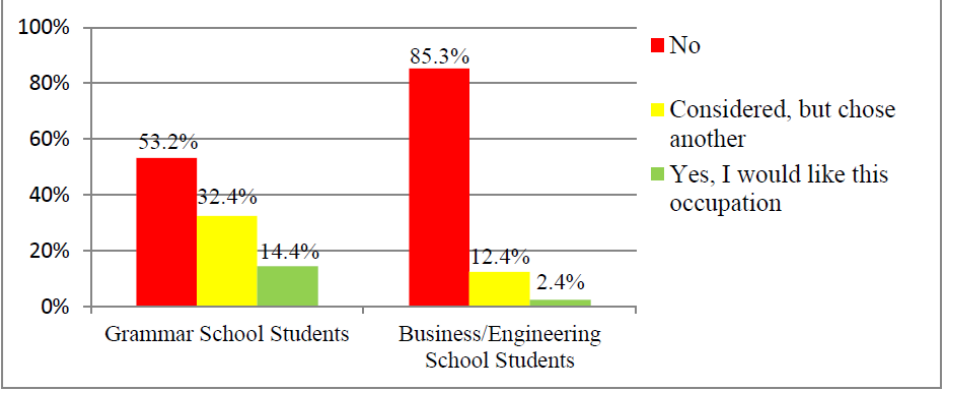

Figure 7: Interest in the secondary school teacher job among future graduates in the Vysocina Region in 2011

Respondents who were to take the graduation exam in the Vysocina Region showed the least interest in the nursing job. As seen in Fig. 8, only 6 males would like to do this job (1.6\%), all of them grammar school students. This possibility was considered by 32 boys (8.3\%). Grammar school students prevailed (28), while only 4 were from the business/engineering schools (4).

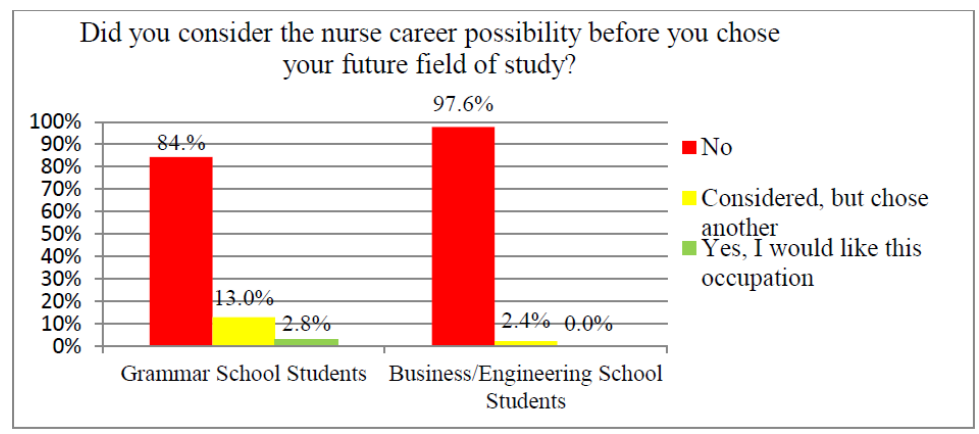

Figure 8: Interest in the nursing job among the future graduates in the Vysocina Region in 2011 
A total of $7.3 \%$ of respondents would like to work in the social work field (see Fig. 9). Most of them are among grammar school students (21) while students of the business/engineering schools also showed some interest (7). Almost 20\% of the males had contemplated this career in the past. Again, grammar school students prevail (50) over the business/engineering school students (24).

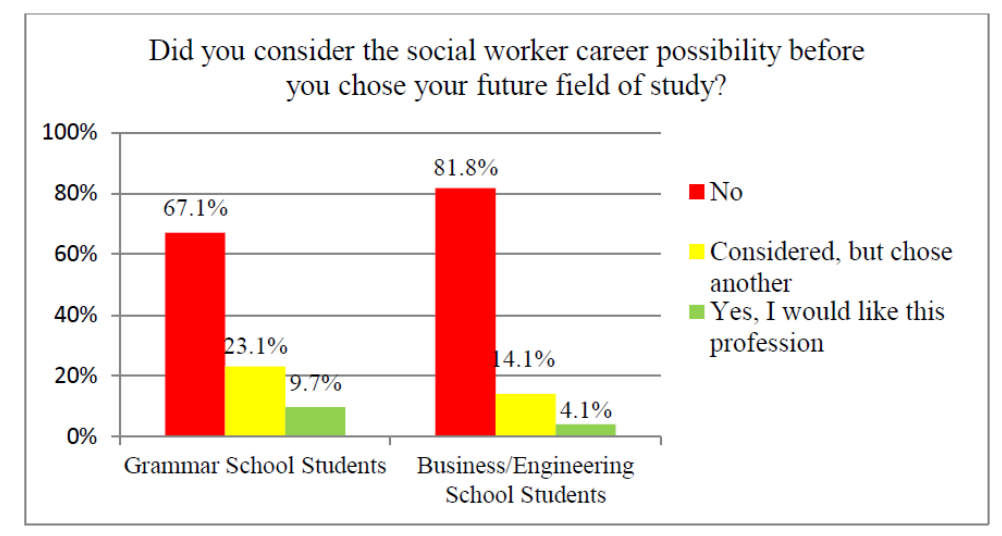

Figure 9: Interest in the social worker job among the future graduates in the Vysocina Region in 2011

Of the offered specializations, most boys preparing for the graduation examination showed interest in those fields of study that would enable them to work as a secondary school teacher $(9.07 \%)$. The social worker was the second most frequently chosen option $(7.25 \%)$. A career of a nurse was the least appealing $(1.55 \%)$.

\section{Discussion}

The objectives of the research were to try to map the views of the secondary school population in the Vysocina Region: to find out about their interest in educational, health care and social careers, and to analyse choice factors. The research proved that future graduates in the Vysocina Region considered the factor of career security to be the most important for their decision on the future field of study. A major role was also played by the prestige of the job they would have after they completed the studies. The "profitability" had a strong influence, too. Unlike Soukalova's findings (2009), future graduates in the Vysocina Region deny that friends or parents have impact on their decision on their choice of the field of study. The respondents had been heavily exposed to information related to the recession. However, only $5.4 \%$ of them admitted an active search for this sort of information. Yet, the media influence is remarkable - more than $63 \%$ of the future graduates took regular notice of events related to economic problems. A mere $6.5 \%$ of the respondents did not follow the information at all. According to the survey, the influence of unemployment in the households of the future graduates was not significant. This fact had a major, or rather important influence on the selection of the future field of study for only $9.2 \%$ of the respondents. The further analysis, using Spearman's rank correlation coefficients, proved very weak causality between the motives of "the field of study is currently profitable and "my friends decided to study this field" on one side and "the tendency to choose a female profession" on the other. Those who tend to choose education, nursing or social works as their future occupation are less affected by the profitability of the job or friends' opinion. There was no correlation between the media coverage on the recession and unemployment in the household and the tendency to 
choose a 'female' profession. Nevertheless, male students, future graduates, were considering education, nursing or social works as their future occupation, a high percentage of the male students chose education (slightly over $10 \%$ in total); nursing and social works were the least popular. For the future research, it would be recommended to use a combined research that would integrate quantitative and qualitative methods. The focus should be on the factors/drivers that repulse male students from choosing nursing or social works as their major education.

\section{Conclusion}

A minority of male students, future graduates in the Vysocina Region in 2010/2011, chose education, nursing or social works as their future occupation. A rather important segment of respondents was considering this profession (especially education), but then selected another. The factor of career security plays the most important role in the decision-making process of the male students/future graduates. Prestige of the job they will have after they graduate the studies is of a high importance as well, and the "profitability" of the profession had a strong influence, too. The further analysis, using Spearman's rank correlation coefficients, proved very weak causality between the motives of "the field of study is currently profitable" and "my friends decided to study this field" on one side and "the tendency to choose a female profession" on the other.

\section{Acknowledgements}

We would like to thank the Department of Statistics of the Vysocina Region for useful data and doc. PhDr. Michal Lošták, $\mathrm{Ph}$. D. from the Czech University of Life Sciences Prague for his valuable comments and advice.

\section{References}

Avery, C., Hoxby C.M. (2004). ,Do and should financial aid packages affect students' college choice?' In C.M.Hoxby (Ed.), College choices: The economics of where to go, and how to pay for it. Chicago: University of Chicago Press.

Briggs, S. (2006). ,An exploratory study of the factors influencing undergraduate student choice: The case of higher education in Scotland'. Studies in Higher Education 31: 705-22.

Briggs, S., and A. Wilson (2007). ,Which university? A study of the influence of cost and information factors on Scottish undergraduate choice', Journal of Higher Education Policy and Management, 29: 57-72.

Cabrera, A. F., La Nasa, S. M. (2000), ,Understanding the college-choice process', New Directions for Institutional Research, 107, 5-21.

Chalupova, M., Boruvkova, J. (2012), ,Strategy of the choice of the field of study at the university or college among senior male students in Vysocina Region - research report', not published yet.

DesJardins, S. L., Ahlburg, D. A., McCall, B. P. (2006). ,An integrated model of application, admission, enrollment, and financial aid', Journal of Higher Education, 77(3), 381-429.

Dill, D. (1997), ,Higher education markets and public policy', Higher Education Policy 10:167-85.

Dolinski, A. (2010), ,The adequacy of the information that students utilize when choosing a college: an attribute imortance and information sufficiency approach', College Student Journal 44. 3,762-776. 
Galloti, K. M., Mark, M. C. (1994), ,How do high school students structure an important life decision? A short-term longitudinal study of the college decision-making process', Research in Higher Education, 35 (5), 1994, 589-607.

Hossler, D. R., Gallagher, K.S. (1987) ,Studying student college choice. A three-phase model and the implications for policymakers', College and University, 62(3), 207-222.

Hossler, D., Schmit, J., Vesper, N. (1999) Going to college: How social, economic, and educational factors influence the decisions students make. Baltimore: John Hopkins University Press.

Hossler, D., Stage, F. K. (1992). ,Family and high school experience influences on the postsecondary educational plans of ninth-grade students', American Educational Research Journal, 29(2), 425-451.

Hoyt, J.E., Brown, A. (2003). ,Identifying college choice factors to successfully market your institution', College and University, Spring: 3-10.

Jackson, G.A. (1982). ,Public efficiency and private choice in higher education', Education Evaluation Policy Analysis, 4: 37-47.

Kallio, R.E. (1995). ,Factors influencing the college choice decisions of graduate students', Research in Higher Education, 36: 109-24.

Kanter, R. M. (1993). Men and Women of the Corporation, BasicBooks, New York, NY, ISBN-10: 0465044549.

Lackland, A. C. (2001) ,Students' choices of college majors that are gender traditional and nontraditional', Journal of College Student Development 42(1), 39-47.

Litten, L. H. (1982). Different strokes in the applicant pool: Some refinements in a model of student college choice. The Journal of Higher Education, 53(4), 383-402.
Martin, N., Dixon, P. (2001) ,Factors influencing students' college choice', Journal of College Student Development 32, 253257.

Menclova, L, Bastova, J. ,Vysokoškolský student v České republice roku 2005 (University student in the Czech Republic in 2005) (2005)’ Prague: Ministerstvo školstoí, mládeže a tělovýchovy, Centrum pro studium vysokého školství, ISBN 80-86302-35-0.

MINISTRY OF EDUCATION, Youth and Sports of the Czech Republic. The Strategic Plan for the Scholarly, Scientific, Research, Development, Innovation, Artistic and Other Creative Activities of Higher Education Institutions for 2011-2015 [online]. 2012. pub. Prague, 2011 [cit. 2012-06-23]. Retrieved from: www.msmt.cz

Minksova, L. (2010) ,Vysokoškoláci - přehled hlavních sociologických výzkumů realizovaných v ČR (University students - review of the main sociological researches in the Czech Republic)', Data a výzkum - SDA Info 2010, Vol. 4, No. 1: 39-60.(c) Sociologický ústav AV ČR, v.v.i., Praha 2010.

Murphy, P. (1981). ,Consumer buying roles in college choice: Parents' and students' perceptions', College and University 56: 140-50.

Moogan, Y. (2011) ,Can a higher education institution's marketing strategy improve the student-institution match?', The International Journal of Educational Management25. 6, 570-589.

Perna, L. W. (2008). ,Understanding High School Students' Willingness to Borrow to Pay College Prices', Research in Higher Education, 49(7), 0361-0365.

Porter S.R., Umbach, P.D. (2006) ,College major choice: an analysis of person-environment fit', Research in Higher Education, Vol. 47, No. 4, DOI: 10.1007/s11162-005-9002-3. 
Sanders, N. F. (1986) ,The college selection process: Research within the twelfth-grade marketplace', The Journal of College Admissions, 111, 1986, 24-27.

Simoes, C., Soares, A.M. (2010) ,Applying to higher education: information sources and choice factors', Studies in Higher Education Vol. 35, No. 4, 371-389, ISSN 0307-5079 print.

Soukalova, R. (2009), Forms of Communication of Universities with Target Groups Focused on Popularization of Science and Research Results', V. International Conference on Applied Bussiness Research ICABR 2009, s. 1352, ISBN 978-7375-325-2, Publisher Mendel Unversity in Brno.

Vrontis, D., A. Thrassou, and Y. Melanthiou. (2007). ,A contemporary higher education student choice model for developed countries'. Journal of Business Research 60: 879-989.

Veloutsou, C., J.W. Lewis, and R.A. Paton. (2004). University selection: Information requirements and importance'. International Journal of Educational Management 18: 160-71.

Zar, J.H. (1974). ,Probabilities for Spearman rank correlation coefficients'. Behavior Research Methods, Vol. 6, No. 3, DOI: 10.3758/BF03210903. 